www.nature.com/ja

\title{
Indole alkaloids from marine-derived fungus Aspergillus sydowii SCSIO 00305
}

\author{
Fei He${ }^{1}$, Yu-Lin Sun ${ }^{1}$, Kai-Sheng Liu ${ }^{2}$, Xiao-Yong Zhang ${ }^{1}$, Pei-Yuan Qian ${ }^{3}$, Yi-Fei Wang ${ }^{2}$ and Shu-Hua Qi ${ }^{1}$
}

The Journal of Antibiotics (2012) 65, 109-111; doi:10.1038/ja.2011.117; published online 21 December 2011

Keywords: Aspergillus sydowii; cytotoxicity; fungus; indole alkaloid

Marine microorganisms have proved to be an important source of pharmacologically active metabolites, and a growing number of marine-derived fungi have been reported to produce metabolites with unique structures and interesting biological activities. ${ }^{1,2}$ The genus Aspergillus (Moniliaceae), with over 180 species, has attracted considerable attention as a rich source of alkaloids, terpenoids, xanthones, polyketides and etc, some of which showed antifungal, antibacterial, anti-HIV and cytotoxic activities. ${ }^{3-5}$ In order to obtain new bioactive metabolites from marine fungi, we investigated on the marine fungal strain Aspergillus sydowii SCSIO 00305 isolated from a healthy tissue of Verrucella umbraculum. Bioassay-guided fractionation led to the isolation of a new indole diketopiperazine alkaloid, cyclotryprostatin E (1), together with nine known ones, [4-(2-methoxyphenyl)-1-piperazinyl][(1-methyl-1H-indol-3-yl)]-methanone (2), cyclotryprostatin B (3), ${ }^{6}$ fumiquinazoline D (4), ${ }^{7}$ fumitremorgin $\mathrm{B}$ (5) ${ }^{8}$ fumiquinazoline $\mathrm{C}(6),{ }^{7}$ fumiquinazoline $\mathrm{B}(7),{ }^{7}$ fumiquinazoline A $(8),{ }^{7}$ fumiquinazoline $\mathrm{F}(9),{ }^{7}$ fumiquinazoline $\mathrm{G}(\mathbf{1 0})^{7}$ from a culture broth of the strain. The structures of compounds (1) and (2) were characterized by spectroscopic data interpretation. Compound (2) was a synthetical compound, however, no reference for it. The NMR data and biology source of (2) were reported for the first time. We present herein the fermentation, isolation, structure elucidation and cytotoxicity of compounds (1) and (2).

Compound (1) was obtained as pale yellow powder with the molecular formula $\mathrm{C}_{23} \mathrm{H}_{29} \mathrm{~N}_{3} \mathrm{O}_{6}$ deduced from NMR spectra and positive HRESIMS (found $466.1953[\mathrm{M}+\mathrm{Na}]^{+}$, calculated 466.1954). The UV bands $(221,293 \mathrm{~nm})$ and IR absorptions at 3400, 3312, 1664 and $1653 \mathrm{~cm}^{-1}$ indicated the presence of conjugated system, hydroxyl and carbonyl groups. The ${ }^{1} \mathrm{H}$ NMR spectrum of (1) showed two methyl groups ( $\delta_{\mathrm{H}} 1.34$ and 1.47), two methoxyl groups $\left(\delta_{\mathrm{H}} 3.41\right.$ and $3.83)$, and three aromatic protons $\left[\delta_{\mathrm{H}} 7.46(\mathrm{~d}, J=9.0 \mathrm{~Hz}, \mathrm{H}-16), 6.75\right.$ (dd, $J=2.5,9.0 \mathrm{~Hz}, \mathrm{H}-17), 6.95$ (d, $J=2.5 \mathrm{~Hz}, \mathrm{H}-19)]$. The ${ }^{13} \mathrm{C}$ and DEPT NMR spectra showed signals for 23 carbons, including two methyls $\left(\delta_{\mathrm{C}} 29.1,31.5\right)$, four methylene groups $\left(\delta_{\mathrm{C}} 22.7,30.9,46.4\right.$ and $50.8)$, one oxygenated methine carbon $\left(\delta_{C} 77.6\right)$, two oxygenated quaternary carbons $\left(\delta_{\mathrm{C}} 71.2\right.$ and 87.3), eight olefinic carbons, and two amide carbonyl groups $\left(\delta_{\mathrm{C}} 167.8\right.$ and 169.0). These NMR data of (1) showed similarity to those of $(3),{ }^{3}$ which suggested that $(\mathbf{1})$ was an indole diketopiperazine alkaloid. A spin coupling system of $\mathrm{H}_{2}-7 / \mathrm{H}_{2}$ $8 / \mathrm{H}_{2}-9$ in the ${ }^{1} \mathrm{H}_{-}{ }^{1} \mathrm{H}$ COSY spectrum (Figure 1), combined with HMBC correlations from H-16 to C-14/C-18/C-20, from H-19 to C-15/C-17/C-18/C-20, from H-3/H $\mathrm{H}_{2}-7$ to C-5, and from H-6 to C-11 (Figure 1), further confirmed the suggestion. Comparison of ${ }^{1} \mathrm{H}$ - and ${ }^{13} \mathrm{C}$ NMR data of (1) with those of cyclotryprostatin B (3) revealed that a tri-substituted double bond $\left(\delta_{C} 123.5\right.$ and 137.9) in (3) was replaced by an oxygenated quaternary carbon $\left(\delta_{\mathrm{C}} 71.2\right)$ and a methylene group $\left(\delta_{\mathrm{C}} 50.8\right)$ in (1). In the HMBC spectrum (Figure 1 ), correlations from $\mathrm{H}_{3}-23 / \mathrm{H}_{3}-24 / \mathrm{H}-3$ to $\mathrm{C}-21 / \mathrm{C}-22$ suggested the assignment of $\mathrm{C}-21\left(\delta_{\mathrm{C}} 50.8\right)$ and $\mathrm{C}-22\left(\delta_{\mathrm{C}} 71.2\right)$. The relative stereochemistry of (1) was determined by the NOESY spectrum, the magnitude of ${ }^{1} \mathrm{H}-{ }^{1} \mathrm{H}$ COSY coupling constants, and comparison of the ${ }^{13} \mathrm{C}$ NMR data of (1) with those of (3). The observed NOE correlations between $\mathrm{H}-3$ and $\mathrm{H}_{3}-24 / \mathrm{H}_{2}-21$, between $\mathrm{H}_{3}-24$ and $\mathrm{H}_{2}-21$, and between $\mathrm{H}-6$ and $\mathrm{H}-7 \alpha / \mathrm{H}-8 \alpha$, together with nearly identical carbon chemical shift of C-12 $\left(\delta_{\mathrm{C}} 87.3\right.$ in (1) and 84.7 in (3)) and C-13 $\left(\delta_{C} 77.6\right.$ in (1) and 76.8 in (3)), indicated that (1) had the same relative configuration as 3 .

Compound (2) was isolated as pale yellow crystals with the molecular formula $\mathrm{C}_{21} \mathrm{H}_{23} \mathrm{~N}_{3} \mathrm{O}_{2}$ deduced from HRESIMS $(\mathrm{m} / \mathrm{z}$ at $350.1865[\mathrm{M}+\mathrm{H}]^{+}$, calc. 350.1869$)$. The ${ }^{1} \mathrm{H}-,{ }^{13} \mathrm{C}$-, and DEPT NMR spectra displayed 18 carbon signals, including one conjugated carbonyl group $\left(\delta_{\mathrm{C}} 168.9\right)$, nine methines, one methoxyl $\left(\delta_{\mathrm{H}} 3.84, \delta_{\mathrm{C}} 56.0\right)$, one methyl $\left(\delta_{\mathrm{H}} 3.84, \delta_{\mathrm{C}} 33.3\right)$, one methylene $\left(\delta_{\mathrm{C}} 52.4\right)$, and five quaternary carbons. Three spin coupling systems $(\mathrm{H}-5 / \mathrm{H}-6 / \mathrm{H}-7 / \mathrm{H}-8$, $\mathrm{H}-20 / \mathrm{H}-21 / \mathrm{H}-22 / \mathrm{H}-23$, and $\mathrm{H}-13(17) / \mathrm{H}-14(18))$ deduced from ${ }^{1} \mathrm{H}-{ }^{1} \mathrm{H}$ COSY spectrum, together with $\mathrm{HMBC}$ correlations from $\mathrm{H}-5$

\footnotetext{
${ }^{1}$ Key Laboratory of Marine Bio-resources Sustainable Utilization/Guangdong Key Laboratory of Marine Materia Medica/RNAM Center for Marine Microbiology, South China Sea Institute of Oceanology, The Chinese Academy of Sciences, Guangzhou, China; ${ }^{2}$ Guangzhou Jinan Biomedicine Research and Development Center, Guangzhou, China and ${ }^{3}$ Hong Kong University of Science and Technology/Department of Biology, Hong Kong, China

Correspondence: Dr S-H Qi, Key Laboratory of Marine Bio-resources Sustainable Utilization/Guangdong Key Laboratory of Marine Materia Medica/RNAM Center for Marine Microbiology, South China Sea Institute of Oceanology, The Chinese Academy of Sciences, 164 West Xingang Road, Guangzhou 510301 Guangdong, China. E-mail: shuhuaqi@scsio.ac.cn
}

Received 2 August 2011; revised 8 November 2011; accepted 23 November 2011; published online 21 December 2011 
to C-3/C-7/C-9, from $\mathrm{H}-2$ to $\mathrm{C}-3 / \mathrm{C}-4 / \mathrm{C}-9$, and from $\mathrm{H}-8$ to $\mathrm{C}-4 / \mathrm{C}-6$ suggested the existence of one indolyl group, one piperazinyl group, and one 1,2-disubstituted phenyl group. One methyl group and one methoxyl group were deduced to be located at N-1 and C-19, respectively, from the observation of $\mathrm{HMBC}$ correlations from $\delta_{\mathrm{H}}$ $3.84(6 \mathrm{H}, \mathrm{s})$ to $\mathrm{C}-2 / \mathrm{C}-9 / \mathrm{C}-19$. This information coupled with the key HMBC correlations from $\mathrm{H}-2, \mathrm{H}-13$ and $\mathrm{H}-17$ to $\mathrm{C}-11$ and from $\mathrm{H}-14$ and $\mathrm{H}-16$ to $\mathrm{C}-18$ enabled us to establish the structure of (2) as shown in Figure 2. We proposal that chorismate acid may be a biogenetic precursor for (2).

Compounds (1) and (2) were screened for their cytotoxicity against A549 (lung cancer cell line), A375 (human melanoma cell line) and Hela (Human cervical carcinoma cell) cell lines, using the MTT method with cis-platin as positive control. Compound (2) showed significant cytotoxicity against $\mathrm{A} 375$ cell lines with $\mathrm{IC}_{50}$ (half maximal inhibitory concentration) value of $5.7 \mu \mathrm{m}$. Compound (1) had no obvious cytotoxicity towards the above mentioned three cell lines.

\section{EXPERIMENTAL PROCEDURE}

\section{Taxonomy}

The fungus A. sydowii SCSIO 00305 was isolated from a healthy tissue of $V$. umbraculum collected from Sanya, Hainan Province, China, and was identified by Dr Xiaoyong Zhang, and a voucher specimen (A. sydowii SCSIO 00305) has been deposited in the RNAM Center for Marine Microbiology, South China Sea Institute of Oceanology, Chinese Academy of Sciences.

\section{Fermentation, isolation and identification of compounds}

The fungus strain A. sydowii SCSIO 00305 was cultivated in $500 \mathrm{ml}$ Erlenmeyer flasks containing $100 \mathrm{ml}$ of the production medium composed of glucose $1 \%$, maltose $2 \%$, mannitol $2 \%$, yeast extract $0.3 \%$, monosodium glutamate $1 \%$, $\mathrm{MgSO}_{4} \cdot 7 \mathrm{H}_{2} \mathrm{O} \quad 0.03 \%, \mathrm{KH}_{2} \mathrm{PO}_{4} \quad 0.05 \%$ and sea water 51 (pH 7.2 before sterilization), and cultured without shaking at $28^{\circ} \mathrm{C}$ for 20 days. The EtOAc extract of mycelia $(800 \mathrm{mg})$ was chromatographed on RP-C 18 column using gradient elution from $5 \% \mathrm{MeOH} / \mathrm{H}_{2} \mathrm{O}$ to $100 \% \mathrm{MeOH}$, to give four fractions. Fraction A $\left(\mathrm{MeOH} / \mathrm{H}_{2} \mathrm{O}, 35 \% \mathrm{v} / \mathrm{v}\right.$ elution, $\left.100 \mathrm{mg}\right)$ was further purified by semi-preparative reversed-phase $\mathrm{HPLC}\left(\mathrm{MeOH} / \mathrm{H}_{2} \mathrm{O} 45 \% \mathrm{v} / \mathrm{v}, 3 \mathrm{ml} / \mathrm{min}\right.$, detector $230 \mathrm{~nm})$ to yield (5) $\quad\left(t_{\mathrm{R}}=23.1 \mathrm{~min}\right), \quad(6) \quad\left(t_{\mathrm{R}}=28.0 \mathrm{~min}\right), \quad(8)$ $\left(t_{\mathrm{R}}=32.5 \mathrm{~min}\right)$. Fraction $\mathrm{B}\left(\mathrm{MeOH} / \mathrm{H}_{2} \mathrm{O}, 55 \% \mathrm{v} / \mathrm{v}\right.$ elution, $\left.120 \mathrm{mg}\right)$ was further purified by semi-preparative reversed-phase HPLC $\left(\mathrm{MeOH} / \mathrm{H}_{2} \mathrm{O} 50 \% \mathrm{v} / \mathrm{v}\right.$,
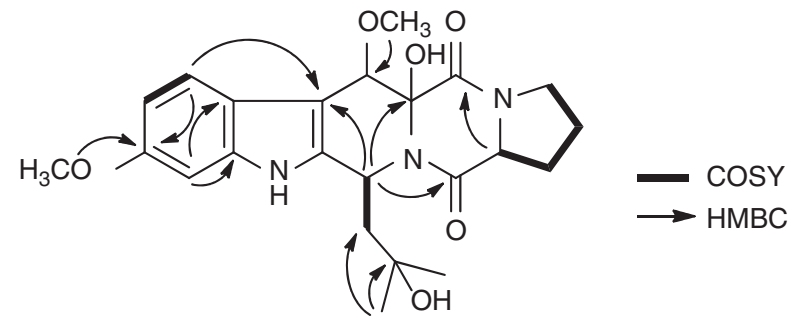

1

Figure 1 Key correlations of COSY (bold line) and HMBC (arrow) of 1.
$3 \mathrm{ml} / \mathrm{min}$, detector $230 \mathrm{~nm})$ to yield (1) $\left(t_{\mathrm{R}}=16.6 \mathrm{~min}\right)$, (4) $\left(t_{\mathrm{R}}=18.9 \mathrm{~min}\right)$, (9) $\left(t_{\mathrm{R}}=22.1 \mathrm{~min}\right)$ and $(\mathbf{1 0})\left(t_{\mathrm{R}}=23.8 \mathrm{~min}\right)$. Fraction $\mathrm{C}\left(\mathrm{MeOH} / \mathrm{H}_{2} \mathrm{O}, 75 \% \mathrm{v} / \mathrm{v}\right.$ elution, $250 \mathrm{mg})$ was further purified by reversed-phase HPLC $\left(60 \% \mathrm{CH}_{3} \mathrm{CN} /\right.$ $\mathrm{H}_{2} \mathrm{O}, 3 \mathrm{ml} / \mathrm{min}$, detector $\left.254 \mathrm{~nm}\right)$ to yield (2) $\left(t_{\mathrm{R}}=12.8 \mathrm{~min}\right)$, (3) $\left(t_{\mathrm{R}}=15.2 \mathrm{~min}\right)$ and $(7)\left(t_{\mathrm{R}}=20.0 \mathrm{~min}\right)$.

Cyclotryprostatin E (1): pale yellow powder; $[\alpha]_{\mathrm{D}}^{25}+28.35\left(\right.$ c $\left.0.23, \mathrm{CH}_{3} \mathrm{OH}\right)$; $\mathrm{UV}\left(\mathrm{CH}_{3} \mathrm{OH}\right) \lambda_{\max }(\log \varepsilon) 209$ (2.91), $251(2.03) ;{ }^{1} \mathrm{H}$ and ${ }^{13} \mathrm{C}$ NMR data see Table 1; IR (KBr) $v_{\max } 3298,2980,2914,1665,1450,1418,1249,1158,1110$, $1028 \mathrm{~cm}^{-1}$; ESIMS $\mathrm{m} / \mathrm{z} 466[\mathrm{M}+\mathrm{Na}]^{+}$; HRESIMS $\mathrm{m} / \mathrm{z} 466.1953[\mathrm{M}+\mathrm{Na}]^{+}$, calculated for $\mathrm{C}_{23} \mathrm{H}_{29} \mathrm{~N}_{3} \mathrm{O}_{6} \mathrm{Na} \mathrm{m} / z$ 466.1954).

[4-(2-methoxyphenyl)-1-piperazinyl] (1-methyl-1H-indol-3-yl)-methanone (2): pale yellow powder; $[\alpha]_{\mathrm{D}}^{25}+33.33\left(c 0.06, \mathrm{CH}_{3} \mathrm{OH}\right)$; UV $\left(\mathrm{CH}_{3} \mathrm{OH}\right) \lambda_{\max }$

Table $1{ }^{1} \mathrm{H}$ - and ${ }^{13} \mathrm{C}$-NMR Data of 1 and $2^{\mathrm{a}}$

\begin{tabular}{|c|c|c|c|c|}
\hline \multirow[b]{2}{*}{ No. } & \multicolumn{2}{|l|}{1} & \multicolumn{2}{|l|}{2} \\
\hline & $\delta_{H}$ & $\delta_{C}$ & $\delta_{H}$ & $\delta_{C}$ \\
\hline 2 & - & 136.2 & $7.64(\mathrm{~s})$ & 133.2 \\
\hline 3 & $6.04(\mathrm{dd}, 6.0,6.0)$ & 49.0 & - & 110.1 \\
\hline 4 & - & - & - & 127.7 \\
\hline 5 & - & 167.8 & $7.73(d, 8.0)$ & 121.4 \\
\hline 6 & $4.31(\mathrm{dd}, 6.0,11.5)$ & 60.7 & $7.22(\mathrm{dd}, 8.0,8.0)$ & 122.1 \\
\hline $7 \alpha$ & $2.46(\mathrm{~m})$ & 30.9 & $7.29(\mathrm{dd}, 8.0,8.0)$ & 123.7 \\
\hline $7 \beta$ & $1.90(\mathrm{~m})$ & & & \\
\hline $8 \alpha$ & $2.11(\mathrm{~m})$ & 22.7 & $7.47(d, 8.0)$ & 111.2 \\
\hline $8 \beta$ & $2.04(\mathrm{~m})$ & & & \\
\hline $9 \alpha$ & $2.22(d, 6.2)$ & 46.4 & - & 138.2 \\
\hline $9 \beta$ & $2.18(\mathrm{~d}, 6.2)$ & & & \\
\hline 10 & - & - & $3.84(\mathrm{~s})^{\mathrm{b}}$ & 33.3 \\
\hline 11 & - & 169.0 & - & 168.9 \\
\hline 12 & - & 87.3 & - & - \\
\hline 13 & $4.81(\mathrm{~s})$ & 77.6 & $3.93^{b}$ & /c \\
\hline 14 & - & 105.1 & $3.08^{b}$ & $52.4^{b}$ \\
\hline 15 & - & 138.2 & - & - \\
\hline 16 & $7.46(d, 9.0)$ & 119.3 & $3.08^{b}$ & $52.4^{b}$ \\
\hline 17 & $6.75(\mathrm{dd}, 2.5,9.0)$ & 110.7 & $3.93^{b}$ & /c \\
\hline 18 & - & 157.7 & - & 142.1 \\
\hline 19 & $6.95(d, 2.5)$ & 96.1 & - & 154.0 \\
\hline 20 & - & 123.7 & $6.98(d, 8.0)$ & 112.9 \\
\hline \multirow[t]{2}{*}{21} & $3.61(\mathrm{~m})$ & 50.8 & $7.04(\mathrm{dd}, 8.0,8.0)$ & 125.0 \\
\hline & $3.78(\mathrm{~m})$ & & & \\
\hline 22 & - & 71.2 & $6.92(\mathrm{dd}, 8.0,8.0)$ & 122.3 \\
\hline 23 & $1.34(\mathrm{~s})$ & 31.5 & $6.99(d, 8.0)$ & 119.8 \\
\hline 24 & $1.47(\mathrm{~s})$ & 29.1 & - & - \\
\hline $\mathrm{CH}_{3} \mathrm{O}-13$ & $3.41(\mathrm{~s})$ & 57.3 & - & - \\
\hline $\mathrm{CH}_{3} \mathrm{O}-18$ & $3.83(\mathrm{~s})$ & 56.1 & - & - \\
\hline $\mathrm{CH}_{3} \mathrm{O}-19$ & - & & $3.84(s)^{b}$ & 56.0 \\
\hline
\end{tabular}

Abbreviations: d, doublet; dd, doublet of doubles; m, multiplet; s, singlet. aAt 500 and $125 \mathrm{MHz}$, respectively; $\delta$ in p.p.m., $J$ in $\mathrm{Hz}$, in $\mathrm{CD}_{3} \mathrm{OD}$.

bOverlapped signals.

${ }^{\mathrm{c}}$ Not observed.
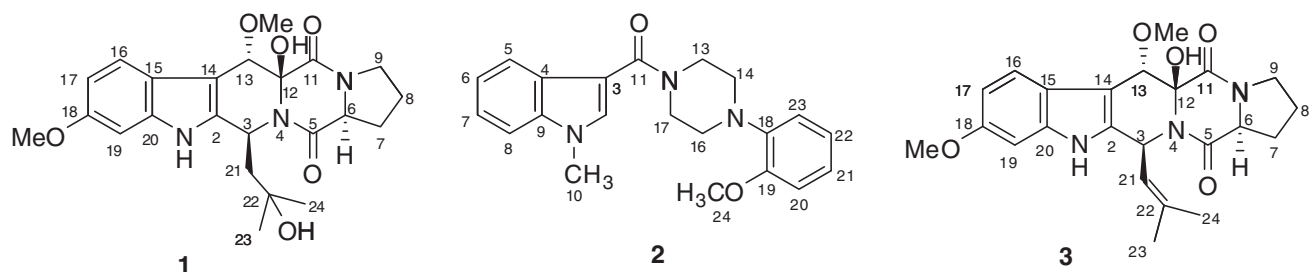

Figure 2 Structures of $\mathbf{1}-\mathbf{3}$. 
( $\log \varepsilon) 286$ (3.84); ${ }^{1} \mathrm{H}$ and ${ }^{13} \mathrm{C}$ NMR data see Table 1; IR (KBr) $v_{\max } 3428,2932$, $2831,1612,1534,1500,1471,1434,1238,1154,1139,747 \mathrm{~cm}^{-1}$; ESIMS $\mathrm{m} / \mathrm{z}$ $466[\mathrm{M}+\mathrm{Na}]^{+}$; HRESIMS $\mathrm{m} / \mathrm{z} 350.1871[\mathrm{M}+\mathrm{H}]^{+}$, calculated for $\mathrm{C}_{21} \mathrm{H}_{23} \mathrm{~N}_{3} \mathrm{O}_{2}$ $\mathrm{m} / \mathrm{z} 350.1868)$.

\section{ACKNOWLEDGEMENTS}

The authors are grateful to the National Basic Research Program of China (grant 2010CB833803), the Knowledge Innovation Program of Chinese Academy of Science (grant KSCX2-EW-G-12B), the National Natural Science Foundation of China and Research Grants Council of Hong Kong (NSFC/ RGC) Program (grant 40931160435), National Science Foundation of China (grant 40976090) and the Research Supported by the CAS/SAFEA International Partnership Program for Creative Research Teams (grant KZCX2-YW-T001) for financial support. We thank Chuan-Rong Li of South China Sea Institute of Oceanology for his help in measuring NMR data, and Jun-Jun Huang of Guangzhou Medical College for her help in measuring ESIMS data.
1 Bugni, T. S. et al. Marine-derived fungi: a chemically and biologically diverse group of microorganisms. Nat. Prod. Rep. 21, 143-163 (2004).

2 Rateb, M. E. et al. Secondary metabolites of fungi from marine habitats. Nat. Prod. Rep. 28, 290-344 (2011).

3 Takagi, M., Motohashi, K. \& Shin-ya, K. Isolation of a new metabolites, JBIR-74 and JBIR-75, from the sponge-derived Aspergillus sp. fS14. J Antibiotics 63, 393-395 (2010)

4 Hosoe, T., Mori, N., Kamano, K., Itabashi, T. \& Yaguchi, T. A new antigungal yellow pigment from Aspergillus nishimurae. J Antibiotics 64, 211-212 (2010).

5 Scherlach, K., Schuemann, J., Dahse, H. M. \& Hertweck, C. Aspernidine A and B, prenylated isoindolinone alkaloids from the model fungus. Aspergillus nidulans $\mathbf{6 3}$, 375-377 (2010).

6 Cui, C. B. et al. Novel mammalian cell cycle inhibitors, cyclotryprostatins A-D, produced by Aspergillus fumigatus, which inhibit mammalian cell cycle at G2/M phase. Tetrahedron 53, 59-72 (1997).

7 Takahashi, C. et al. Fumiquinazoline A-G, novel metabolites of a fungus separated from a Pseudolabrus marine fish. J. Chem. Soc. Perkin. Tran. I 18, 2345-2352 (1995).

8 Masako, N. et al. Total synthesis of fumitremorgin B. Tetrahedron Lett. 27, 6217-6220 (1986) 